DOI 10.7764/rcia.v45i1.1818

PHYTOCHEMISTRY

\title{
Susceptibility of different grapevine (Vitis vinifera L.) cultivars to Diplodia seriata and Diplodia mutila
}

\author{
M. Ramírez, L.M. Pérez, and J.R. Montealegre. \\ ${ }^{1}$ Universidad de Chile, Facultad de Ciencias Agronómicas, Departamento de Sanidad Vegetal, Laboratorio \\ de Fitopatología y Control Biológico de Enfermedades. Casilla 1004, Santiago-Chile. \\ ${ }^{2}$ Asesorías e Inversiones Biostrategy Limitada. Hernando de Aguirre 1372, Providencia, Santiago, Chile.
}

\begin{abstract}
M. Ramírez, L.M. Pérez, and J. Montealegre. 2018. Susceptibility of different grapevine (Vitis vinifera L.) cultivars to Diplodia seriata and Diplodia mutila. Cien. Inv. Agr. XX: 93-98. Canes obtained from one-year-old stems of the grapevine cultivars Cabernet Franc, Malbec, Merlot, Sauvignon Blanc and Syrah (all non-grafted) were used as models to test their susceptibility to Diplodia seriata and Diplodia mutila. The results showed that the mean length of lesions caused by D. mutila was 3.2 times larger than that produced by D. seriata. In addition, the Cabernet Franc and Syrah cultivars were the most susceptible to D. mutila, while Merlot and Malbec were the least susceptible. No significant differences were observed between cultivars inoculated with $D$. seriata. The results are discussed in terms of the susceptibility of the different grapevine cultivars to both pathogens.
\end{abstract}

Keywords: Botryosphaeriaceae, botryosphaeria die-back, grapevine, susceptibility.

\section{Introduction}

Wine and table grapes (Vitis vinifera $\mathrm{L}$.) are important crops covering diverse climate zones in Chile where they are cultivated on an estimated 182,000 ha, of which approximately 130,400 ha are managed for wine grape production (ODEPA, 2015). Botryosphaeria dieback is one of the predominant grapevine trunk diseases worldwide (Bertch et al., 2013). The frequency of symptoms associated with fungal attack on grapevine trunk wood diseases increased significantly worldwide during the last decade, including in Chile. Fungal species belonging

Received Jun 30, 2017. Accepted Mar 20, 2018. Corresponding author: jmonteal@uchile.cl to the Botryosphaeriaceae are responsible for the death of part of the plant, reducing the productivity and profitability of this crop (Gubler et al., 2010). Both D. seriata and D. mutila are associated with the Botryosphaeria die-back in Chile (Díaz et al., 2013; Morales et al., 2012). These fungi have been detected in table grape vineyards where no differences were observed among the Thompson Seedless, Red Globe and Flame Seedless cultivars, which were equally susceptible to infection by $D$. mutila, D. seriata and Spencermartinsia viticola (Morales et al., 2012). In addition, experiments carried out with axenic plants, trunks and shoots of the Carmenère cv. showed that there were no differences in pathogenicity between D. mutila and D. seriata (Díaz et al., 2013). However, the susceptibility of different wine grape cultivars 
to $D$. seriata and D. mutila has not been reported to date. Thus, the objective of this work was to compare the susceptibility of the grapevine cultivars Cabernet Franc, Malbec, Merlot, Sauvignon Blanc and Syrah (all nongrafted) to D. seriata and D. mutila, using detached grapevine canes as a model system.

\section{Materials and methods}

\section{Fungal isolates}

Diplodia seriata (strain 1009) and D. mutila (strain 894), both pathogenic to grapevine plants and well characterized using morphological and molecular tests (Dr. Josep Armengol, Instituto Agroforestal Mediterraneo, Universidad Politécnica de Valencia, España, personal communication), were obtained from a microbiology laboratory fungal collection (Departamento de Sanidad Vegetal, Universidad de Chile). Both strains were cultured in potatodextrose-agar (PDA, Difco) at $25^{\circ} \mathrm{C}$ in the dark for seven days (Úrbez- Torres and Gubler, 2009).

\section{Plant material}

One-year-old healthy canes from the wine grapevine cultivars Cabernet Franc, Malbec, Merlot, Sauvignon Blanc and Syrah (all non-grafted) were collected from local vineyards in the O'Higgins and Metropolitan Regions, Chile. The canes were cut from grapevine plants two weeks before pruning (June 2014 and 2016). Then, the canes were cut in $20 \mathrm{~cm}$ pieces and were maintained at $5{ }^{\circ} \mathrm{C}$ and $20 \%$ humidity for two months before use.

\section{Trials}

In vivo trials were performed using detached canes previously disinfected for three minutes with $70 \%$ ethanol and washed with sterile distilled water. A V-shaped wound was made with a scalpel in the internodes region. Mycelial plugs (6 mm diameter) obtained from pure cultures of $D$. seriata or D. mutila were used in inoculations, and PDA plugs were used for controls. The inoculated wounds were covered with Parafilm, and the detached canes were placed inside plastic boxes with a translucent cover. They were incubated in the dark at $25^{\circ} \mathrm{C}$ and $95 \%$ humidity. Visual observation of the canes was performed weekly to determine the disease's development and to prevent its progress into the nodes. Each independent trial (2014 and 2016) consisted of 10 replicates per each of the five grapevine cultivars tested and was repeated twice. The length of necrotic lesions observed at the internode region after six weeks of incubation was measured on both sides of the inoculation point with calipers after careful removal of the bark (Savocchia et al., 2007; Úrbez-Torres and Gubler, 2009). After the length measurement, transversal sections of canes were obtained to visualize the lesion. The results were analyzed by ANOVA followed by Tukey's test $(\mathrm{p}<0.05)$.

\section{Results}

Necrosis was observed in the internodes region of all the detached grapevine canes inoculated with D. seriata (strain 1009) or with D. mutila (strain 894). Additionally, a V-shaped lesion (a typical symptom of Botryosphaeria die-back) was observed in the transversal sections of the canes, an observation that was used only to confirm that necrosis was a consequence of the inoculation with $D$. seriata or with D. mutila. Oxidation of the tissue was observed in the control inoculated canes as a consequence of wounding. An example of the observations is shown in Figure 1.

The mean length of lesions produced by $D$. seriata or by $D$. mutila in grapevine canes is shown in Figure 2. Significant differences in lesion length were observed among the different grapevine cultivars inoculated with $D$. mutila, while no significant differences were observed among the same cultivars inoculated with $D$. seriata, except for the Malbec cultivar, where significant differences were observed with the controls. The length of oxidation due to mechanical damage 


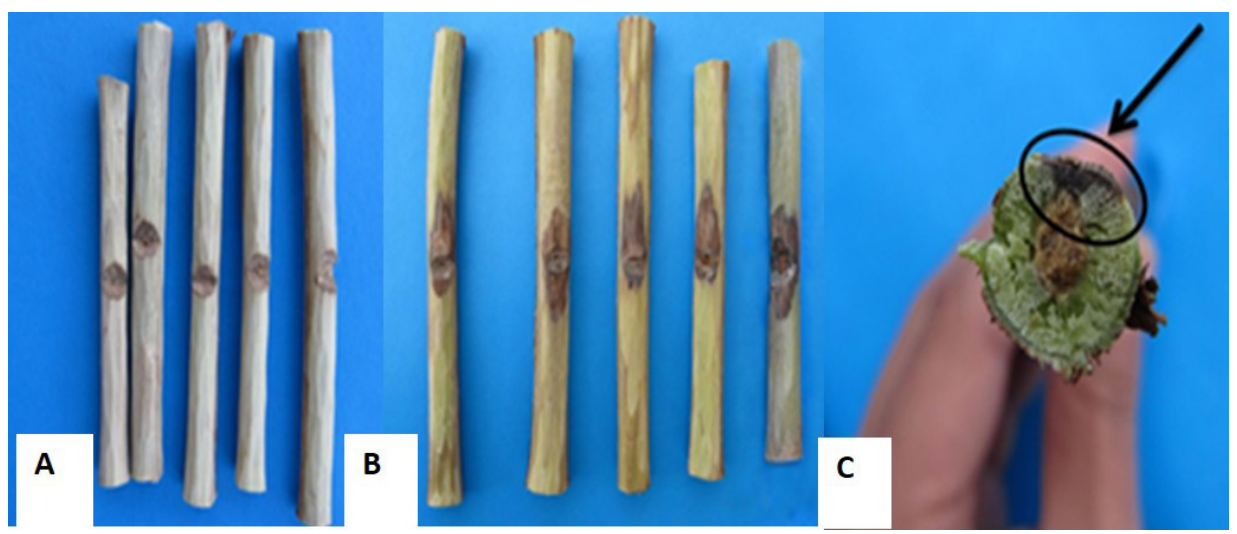

Figure 1. Example of detached canes from different non-grafted cultivars after six weeks incubation in darkness at $25^{\circ} \mathrm{C}$ and 95\% humidity. A) Control canes, B) Canes inoculated with Diplodia seriata (strain 894) and C) V-shaped lesion in transversal section of a cane indicated by the arrow and a circle. Grapevine cultivars (left to right): Cabernet Franc, Syrah, Sauvignon Blanc, Malbec and Merlot.

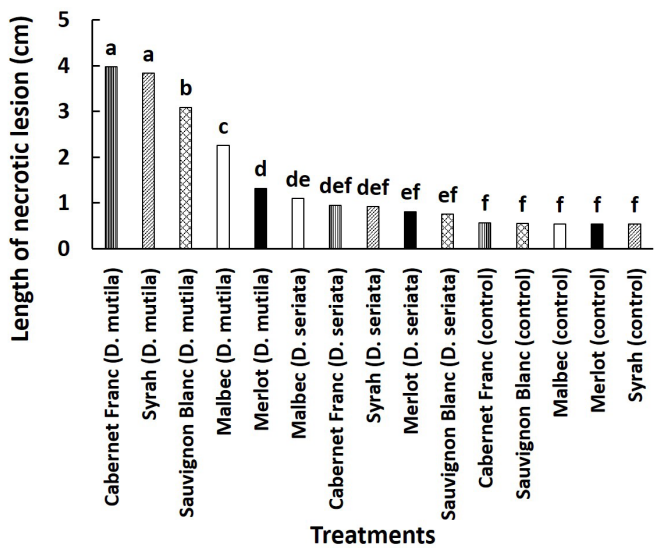

Figure 2. Length of necrotic lesions ( $\mathrm{cm}$ ) caused by Diplodia mutila (strain 1009) and by Diplodia seriata (strain 894) in detached canes from different non-grafted grapevine cultivars (Cabernet Franc, Syrah, Sauvignon Blanc, Malbec and Merlot). Different letters indicate significant differences after ANOVA followed by Tukey's test $(\mathrm{p}<0.05)$.

did not exceed $10.6 \%$ of the length of lesions of inoculated ones.

In addition, the lesions produced by $D$. seriata were shorter than those produced by D. mutila, reflected in the corresponding ratios (Table 1).

\section{Discussion}

Detached canes from different grapevine cultivars (Cabernet Franc, Malbec, Merlot, Sauvignon Blanc and Syrah) showed differences in their susceptibility to D. mutila and D. seriata (Table 1). Cabernet Franc and Syrah were the most susceptible, and Merlot and Malbec were the least susceptible. The difference in susceptibility could be related to the vessel dimension, as was previously established when comparing the susceptibility to Esca of the wine grape cultivars Merlot and Cabernet Sauvignon and the table grape cultivar Thompson Seedless (Pozoulet et al., 2014). Those authors showed that the small size of the vessels in the Malbec cv. was related to their decreased susceptibility to Esca, while the Thompson Seedless cultivar showed the largest vessel size. Similar differences were observed by Travadon et al. (2013), showing that the Thompson Seedless cultivar was the most susceptible to infection by Neofusicoccum parvum, while the least susceptible were the Merlot and Concorde cultivars. Morphological analysis (Pozoulet et al., 2014) showed that vessels from the Merlot cultivar were smaller than those of the Thompson Seedless cultivar. In addition, studies conducted using two-month-old plants of Cabernet Sauvignon, Merlot and Ugni Blanc with 10-12 true leaves showed significant differences in the mean length of the internal necrosis and external canker between the cultivars above mentioned, inoculated with D. mutila and D. seriata (Bellée et al., 2017). Thus, it appears that a correlation exists between vessel size and susceptibility to Esca or other fungi causing grapevine trunk diseases, 
Table 1. Length of lesions produced by Diplodia seriata (strain 1009) and by Diplodia mutila (strain 894) in detached canes of different non-grafted grapevine cultivars.

\begin{tabular}{lcccc}
\hline & $\begin{array}{c}\text { Length of lesion produced by } \\
\text { D. seriata }^{\dagger}(\mathrm{cm})\end{array}$ & $\begin{array}{c}\text { Length of lesion produced by } \\
\text { D. mutila }(\mathrm{cm})\end{array}$ & \multicolumn{2}{c}{ Ratio $^{\ddagger}$} \\
\hline Merlot & 0.27 & 0.78 & 2.89 & $\mathrm{a}$ \\
Malbec & 0.56 & 1.72 & 3.07 & $\mathrm{a}$ \\
Cabernet Franc & 0.38 & 3.41 & 8.97 & $\mathrm{~b}$ \\
Syrah & 0.38 & 3.30 & 8.68 & $\mathrm{~b}$ \\
Sauvignon Blanc & 0.20 & 2.54 & 12.70 & $\mathrm{c}$ \\
\hline
\end{tabular}

†Values correspond to the mean total length of the lesion in treatments minus the total length of the lesion in controls.

¿Different letters indicate significant differences after ANOVA followed by Tukey's test $(\mathrm{p}<0.05)$.

which could explain the differences observed in the susceptibility to D. mutila, among the canes from different grapevine cultivars tested, as well as the difference observed for the Malbec cultivar in response to inoculation with $D$. seriata (Figure 2).

It should also be mentioned that the isohydric characteristic of a specific grapevine cv. could determine a similar susceptibility against different pathogens (Jara-Rojas et al., 2015), as it has been described for the Carménère cultivar using axenic plants, trunks and shoots inoculated with D. mutila and D. seriata (Díaz et al., 2013). Our results were opposed to those of the Carménère cultivar because they showed different susceptibility to D. seriata and D. mutila (Table 1), and are consistent with those of the Syrah cultivar, that has been often considered as anisohydric yet shows near-isohydric behavior (Pou et al., 2012). Furthermore, the fact that all the canes used in this work were obtained from non-grafted grapevine cultivars could have affected the difference in susceptibility to $D$. seriata and $D$. mutila (Table 1). Our results also contradict the results of similar susceptibility to D. mutila found in vine canes from table grapes cultivars (Flame Seedless, Red Globe and Thompson Seedless), which were all grafted on Harmony (Ramírez, M. personal communication), and those achieved by Morales et al. (2012) in which the same cultivars were found equally susceptible to infection by $D$. mutila, D. seriata and S. viticola at the field level. Nevertheless, it cannot be discarded that the table grape cultivars used in our experiments could share similar hydraulic properties and similarly sized vessels (Pouzoulet et al., 2014).

The finding of no significant differences in susceptibility to $D$. seriata observed among the Cabernet Franc, Malbec, Merlot, Sauvignon Blanc and Syrah cultivars (Figure 2) has agreed with previous studies on the susceptibility of different grapevine rootstocks to a single pathogen or disease, where both different and similar susceptibility to certain pathogens have been observed. For example, material from the Sonoma Grapevine Nursery in California showed differences between the different rootstocks analyzed in relation to susceptibility to Phaeomoniella chlamydospora and Phaeoacremonium spp. (Eskalen et al., 2001). However, other reports show that depending on the rootstocks used, no susceptibility differences were observed to certain pathogens, as was reported for the infection status of different viruses (Komar et al., 2010) in three clones of the Vitis vinifera cultivar Savagnin Rose and rootstock genotype (Vitis rupestris, Kober 5BB, or 16149 Couderc). Our results, using detached grapevine canes from wine grape cultivars as a model, are in accordance with those already reported where different and similar susceptibility to certain pathogens could be observed and where no generalization could be deduced.

Comparison of susceptibility to D. mutila and $D$. seriata of the different rootstocks tested showed that the majority were more susceptible to $D$. mutila. This can probably be explained due to 
the D. mutila isolate used in this study, which appears to be more pathogenic than the $D$. seriata one (Figure 1). This agrees with previous reports on Chardonnay grapevines (Pitt et al., 2013), as opposed to the no differences in pathogenicity observed among these pathogens when infecting the table grape cultivars (Morales et al., 2012). Moreover, it is also important to consider that the pathogenicity of a certain pathogen on the same grapevine cultivars could depend on the specific isolate tested, as has been described by Yan et al., (2013).
Therefore, we conclude that different aspects come together in terms of grapevine susceptibility to D. mutila and D. seriata, and the rootstock and vessel size could partially explain the results observed. Among the different grapevine cultivars tested, Cabernet Franc appeared to be more susceptible to $D$. mutila than to $D$. seriata, Syrah cultivars were the most susceptible to $D$. mutila and Merlot and Malbec were the least susceptible. Field experiments using the same grapevine cultivars will be necessary in order to complement our results.

\title{
Resumen
}

\begin{abstract}
M. Ramírez, L.M. Pérez, y J.R. Montealegre. 2018. Susceptibilidad de diferentes cultivares de vid vinífera (Vitis vinifera L.) a Diplodia seriata y Diplodia mutila. Cien. Inv. Agr. XX: 93-98. La susceptibilidad de los cultivares de vid vinífera Cabernet Franc, Malbec, Merlot, Sauvignon Blanc and Syrah (todos patrón Franco) a Diplodia seriata y Diplodia mutila se analizó usando estacas como modelo. Las estacas se obtuvieron de sarmientos de un año de edad. Los resultados mostraron que la longitud promedio de las lesiones producidas por $D$. mutila era 3,2 veces mayor que la producida por D. seriata. Al comparar las lesiones producidas por D. mutila en los diferentes cultivares, se encontró que Cabernet Franc y Syrah fueron los más susceptibles, mientras que Merlot y Malbec fueron los menos susceptibles. Por otra parte, no se observaron diferencias significativas en el tamaño de las lesiones producidas por $D$. seriata en los diferentes cultivares. Los resultados se discuten con relación a la susceptibilidad de diferentes cultivares de vid vinífera al daño producido por ambos patógenos.
\end{abstract}

Palabras clave: Botryosphaeriaceae, brazo muerto de la vid, susceptibilidad, vid.

\section{References}

Bellée, A., G. Comont, A. Nivault, E. Abou-Mansour, C. Coppin, M.C. Dufour, and M.F. Corio Costet. 2017. Life traits of four Botryosphaeraciae species and molecular response of different grapevine cultivars or hybrids. Plant Pathology 66:763-776

Díaz, G.A., J. Auger, X. Besoain, E. Bordeu, and B.A. Latorre. 2013. Prevalence and pathogenicity of fungi associated with grapevine trunk diseases in Chilean vineyards. Cien. Inv. Agr. 40:327-339.
Eskalen, A., W.D. Gubler, and A. Khan. 2001. Rootstock susceptibility to Phaeomoniella chlamydospora and Phaeoacremonium spp. Phytopathol. Mediterr. 40, Supplement, S433-S438.

Gubler, W.D., J.R. Úrbes-Torres, F.P. Trouillas, R. Herche, R.K. Striegler, R.D. Cartright, J. Kreiddy, and J.C. Rupe. 2010. Grapevine Trunk Diseases: Etiology, Epidemiology and Control. Proceedings of the Symposium on Advances in Vineyard Pest Management (R. K. Striegler, A. Allen, S. Jogaiah and J. Harris, eds.) pp. 7-21.

Jara-Rojas, F., S. Ortega-Farías, H. Valdés-Gómez, and C. Acevedo-Opazo. 2015. Gas exchange re- 
lations of ungrafted grapevines (cv. carménère) growing under irrigated field conditions. S Afr J Enol Vitic 36:231-242.

Komar, V., E. Vigne, G. Demangeat, O. Lemaire, and M. Fuchs. 2010. Comparative performance of virus-infected Vitis vinifera $\mathrm{cv}$. Savagnin rose grafted onto three rootstocks. Am. J. Enol. Vitic. 61:68-73.

Morales, A., B.A. Latorre, E. Piontelli, and X. Besoain. 2012. Botryosphaeriaceae species affecting table grape vineyards in Chile and cultivar susceptibility. Cien. Inv. Agr. 39:445-458.

ODEPA, 2015. Catastro vinífero 2015. Oficina de Estudios y Políticas Agrarias. Available at http:// www.odepa.cl/estadisticas/productivas/.

Pitt, W.M., R. Huang, C.C. Steel, and S. Savocchia. 2013. Pathogenicity and epidemiology of Botryosphaeriaceae species isolated from grapevines in Australia. Australasian Plant Pathol. 42:573-582.

Pou, A., H. Medrano, M. Tomàs, S. Martorell, M. Ribas-Carbó, and J. Flexas. 2012. Anisohydric behavior in grapevines results in better performance under moderate water stress and recovery than isohydric behavior. Plant Soil 359:335-349.
Pouzoulet, J., A.I. Pivovaroff, L.S. Santiago, and P.E. Rolshausen.2014. Can vessel dimension explain tolerance toward fungal vascular wilt diseases in woody plants? Lessons from Dutch elm disease and esca disease in grapevine. Frontiers in Plant Science 5:1-11.

Savocchia, S., C. Steel, B. Stodart, and A. Somers. 2007. Pathogenicity of Botryosphaeria species isolated from declining grapevines in sub-tropical regions of Eastern Australia. Vitis, 46(1):27-32.

Travadon, R., P.E. Rolshausen, W.D. Gubler, L. Cadle-Davidson, K. Baumgartner. 2013. Susceptibility of cultivated and wild Vitis spp. to wood infection by fungal trunk pathogens. Plant Disease 97:1529-1536.

Úrbez-Torres, J. and W. Gubler. 2009. Pathogenicity of Botryosphaeriaceae species isolated from grapevine cankers in California. Plant Disease 93:584-592.

Yan, J.Y., Y. Xie, W. Zhang, Y. Wang, J.K. Liu, K.D. Hyde, R.C. Seem, G.Z. Zhang, Z.Y. Wang, S.W. Yao, X.J. Bai, A.J. Dissanayake, Y.L. Peng, X.H. Li. 2013. Species of Botryosphaeriaceae involved in grapevine dieback in China. Fungal Diversity 61:221-236. 